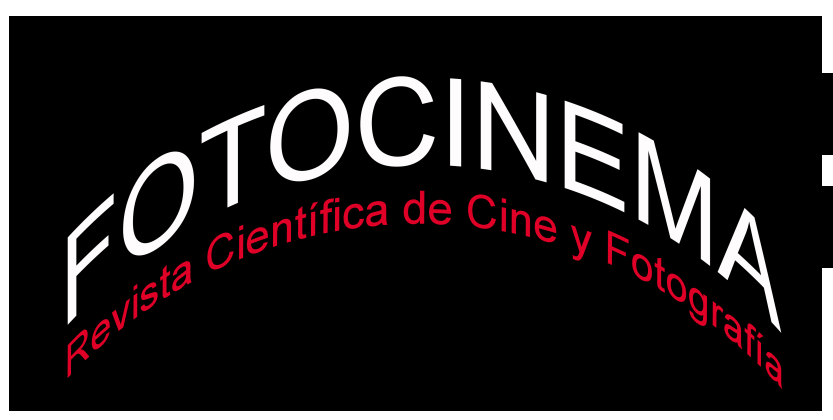

\title{
LA REPRESENTACIÓN DEL DOLOR Y LA PÉRDIDA EN EL CINE DOCUMENTAL. EL CASO DE GEOGRAFÍA DEL DOLOR
}

\author{
THE REPRESENTATION OF THE PAIN AND THE LOSS IN \\ DOCUMENTARY FILM. THE CASE OF GEOGRAFÍA DEL DOLOR
}

\author{
Fabiola Alcalá Anguiano \\ Universidad de Guadalajara, México \\ f.alcala79@gmail.com
}

\section{Resumen:}

Geografía del Dolor es un proyecto documental realizado por la fotoperiodista mexicana Mónica González. Este filme retrata las consecuencias de la guerra contra el narcotráfico, a través del testimonio de familiares que buscan a sus desaparecidos o que reclaman su asesinato.

En este texto planteamos un análisis de la parte audiovisual del proyecto, desde un punto de vista hermenéutico y siguiendo la lógica del discurso retórico. El objetivo es preguntarnos sobre los recursos ético-estéticos que utiliza, y ver si existe alguna concordancia con filmes documentales clásicos, preocupados también por reflexionar sobre la representación del dolor y la pérdida.

\begin{abstract}
:
Geografia del dolor is a documentary project by the Mexican photojournalist Mónica González. It portrays the consequences of the war on drugs, through the testimony of relatives looking for their missing ones or claiming his murder.

Trough this paper we propose an analysis of the audiovisual part of the project, from a hermeneutical point of view and following the logic of rhetorical discourse. The goal is to wonder about the ethical and aesthetic resources used and also to see if there is any agreement with classic documentary films, worried too, to reflect on the representation of pain and loss.
\end{abstract}

Palabras clave:

Cine documental; ética; estética; fotoperiodismo; desaparecidos; dolor y pérdida.

Keywords:

Documentary film; ethics; aesthetics; photojournalism; missing; grief and loss. 


\section{Introducción}

Todo el fetichismo de la imagen fotográfica proviene de esta doble postura: la foto como objeto, se toca, se enmarca, se colecciona, se encierra, se quema, se rompe, se besa, a pesar de que sólo nos muestra lo intocable, lo inaccesible, el recuerdo, la ausencia... Philippe Dubois

Geografia del dolor es un proyecto audiovisual compuesto por una serie de once documentales para la Web, un libro de postales y una exposición fotográfica itinerante. Lo realizó la fotoperiodista mexicana Mónica González. El proyecto narra diferentes historias sobre desapariciones y asesinatos, a raíz de la guerra contra el narcotráfico en México'.

Mónica González ha documentado diferentes eventos relacionados con esta guerra. Durante este ejercicio se dio cuenta de que fotografiar a los cadáveres que amanecían colgados, a las personas a quienes decapitaron y colocaron una cabeza de cerdo para exponerlas en las calles, o tantas otras escenas construidas para aterrorizar y dejar un mensaje intimidatorio, era jugar el juego de los agresores. Sus imágenes podrían ayudar a estos grupos criminales a expandir su control, por lo que decidió dejar de mirar, y de documentar, este "performance de la muerte", como ella lo llama:

... en un momento muchos sólo reprodujimos de manera gráfica la barbarie, después nos dimos cuenta de que necesitábamos hacer algo más y ese algo más era voltear hacia las consecuencias de eso que fotografiamos, ya que cuando tú retratas un hecho violento, sin reflexionar sobre lo que ves, sólo estás reproduciendo ese performance de la muerte que proviene de los victimarios y esa no es ni debería ser nuestra labor. Uno como fotógrafo tiene que romper esa inercia e irse a las consecuencias de los hechos para contar

${ }^{1}$ El proyecto es anterior a la desaparición de los 43 normalistas de Ayotzinapa, Guerrero. http://www.geografiadeldolor.com/

${ }^{2}$ La decisión de trabajar sólo con los videos se debe a que las fotografías de la exposición y las postales del libro -los otros productos del proyecto- se encuentran dentro de los videos, y 
en la imagen: quiénes son las víctimas, en qué condiciones las están dejando y qué están haciendo éstas para salir para adelante (Franco, 2014).

Ella decidió darle voz a las víctimas, a los sobrevivientes de esta barbarie surreal, convirtiendo este cambio de foco en el punto de partida de su proyecto Geografía. Además se dispuso a hacerlo no sólo en imágenes fijas sino también en vídeos documentales y con textos impresos, buscando que éstos se adecuaran más a la necesidad de difundir los testimonios de los familiares, y no exclusivamente a exponer su retrato.

Esta reflexión por parte de la periodista desde la profesión es también una preocupación del cine documental: cómo el representar el dolor y la pérdida conlleva una serie de decisiones éticas que casi siempre tienen respuesta en la estética. Es decir, encontrando ese recurso con el que se puede acceder a representar sin lastimar, pero sin dejar de enfatizar en el mensaje que se quiere transmitir. Muchos documentalistas se han cuestionado cómo tratar estos temas y han ido encontrando recursos formales para hacerlo desde la consideración y el respeto a las víctimas, creando así una serie de gestos que desde la puesta en escena, la fotografía, la banda sonora o el montaje, se colocan a la altura de estas necesidades éticas.

El objetivo de este texto es trazar un diálogo entre la tradición documental y el proyecto de la fotoperiodista mexicana, con la intención de actualizar y reflexionar sobre algunas de las interrogantes éticas y estéticas de la representación del dolor y la pérdida en imágenes, independientemente de si son fijas o en movimiento, de si son proyectadas o expuestas en la Web.

Plantearemos un análisis desde el punto de vista hermenéutico, en el que los contextos de la obra nos permitan extraer las categorías de análisis para volver a la misma. Nos centraremos en el estudio de los once videos, de aproximadamente doce minutos de duración, que conforman la parte audiovisual del proyecto $^{2}$. Dividiremos el análisis siguiendo el esquema de un

${ }^{2}$ La decisión de trabajar sólo con los videos se debe a que las fotografías de la exposición y las postales del libro -los otros productos del proyecto- se encuentran dentro de los videos, y no difieren en propuesta formal, ni de contenido. 
discurso retórico, ya que nos sumamos a la idea de Bill Nichols de que "todo documental es en sí mismo un acto retórico” (2007, p. 5). Por lo que nos interesa revisar sus argumentos principales, el orden en que se presentan y las figuras que se utilizan.

En este recorrido pretendemos construir una tipología de imágenes, recursos ético-estéticos, que aparecen en este trabajo documental y que tienen eco en piezas documentales anteriores como respuesta al tratamiento del dolor y la pérdida. Pensamos que esta tipología, en construcción y discutible, también aporta a la reflexión sobre la teoría documental que se desprende de cada análisis, y que muchas veces se abandona por considerarla útil sólo para la interpretación del caso particular.

\section{Marco teórico-metodológico}

El origen del trabajo hermenéutico, como sabemos, se remonta a los aportes de Hans-Georg Gadamer, incluidos en los dos volúmenes de Wahrheit und Methode (2007) en los que desarrolla la hermenéutica como el arte de la comprensión en sí misma. Antes del trabajo de Gadamer, la hermenéutica sólo se limitaba a funcionar como técnica de interpretación de textos literarios o jurídicos. El pensador alemán transforma la técnica en filosofía, en una actitud, o bien, en una conciencia:

El que quiere comprender un texto tiene que estar en principio dispuesto a dejarse decir algo por él. Una conciencia formada hermenéuticamente tiene que mostrarse receptiva desde el principio para la alteridad del texto. Pero esta receptividad no presume ni "neutralidad" frente a las cosas ni tampoco autocancelación, sino que incluye una matizada incorporación de las propias opiniones previas y prejuicios. Lo que importa es hacerse cargo de las propias anticipaciones, con el fin de que el texto mismo pueda presentarse en su alteridad y obtenga así la posibilidad de confrontar su verdad objetiva con las propias opiniones previas (pp. 335-336).

La hermenéutica, según su trabajo, es la ciencia y arte de la interpretación, y más que un método como tal, es la herramienta de análisis que hace hincapié 
en el objeto y en sus propios contextos para realizar una adecuada interpretación. Si trasladamos este modelo al análisis fílmico, debemos reconocer en qué contextos surge la obra a analizar, y extraer de ellos las categorías, o los indicadores, que servirán para interpretarla de mejor manera.

En esta línea, los dos principales contextos que enmarcan el proyecto audiovisual de Geografía son: el fotoreportaje, como oficio de la realizadora, y la tradición documental. Es decir, la teoría documental en sí, y sobre todo aplicada a otros ejemplos de análisis de filmes en los que se trabaje con la representación del dolor y la pérdida.

Sobre el primer contexto, debemos señalar que la realizadora toma una serie de decisiones que marcan el proyecto a partir de su propia experiencia como reportera gráfica, y que esta experiencia se puede traducir en términos de “emociones”, como señala Barthes, y que Catalá (2006) recupera como concepto para hablar de cómo las "emociones" de Jean Vigo condicionaron las imágenes de su película documental:

...Barthes lo que dice exactamente es que una fotografía puede ser objeto de tres prácticas y añade de forma muy oportuna, “o de tres emociones o de tres intenciones”. A nosotros, a propósito de Vigo, nos interesa regresar, dejando atrás los rigores posestructuralistas, a la práctica más tradicional, la del operator, o sea la del autor propiamente dicho, para contemplarla precisamente desde esa categoría emocional que Barthes coloca al mismo nivel que la intención y la práctica... Al autor cinematográfico, al que apenas se le supone capacidad de pensamiento, inmerso como está en la estructura de la producción industrial, menos se le permiten las emociones. Pero el camino que llevó a Jean Vigo hasta Niza fue un transcurso cargado emocionalmente hasta lo imposible y $\grave{A}$ propos de Nice es el resultado de esta tensión emocional acumulada a través de una biografía siniestra (2006, p.44).

Este planteamiento no es muy habitual porque, como podemos imaginar, encontrar las emociones del autor en las imágenes cinematográficas no en todos los casos resulta sencillo. sin embargo, y por eso comenzamos este 
texto explicando la implicación de la realizadora con el tema y sus actores, en algunos casos es un gesto imprescindible para entender la película.

Por otro lado, la realizadora y sus emociones resultan importantes ya que, a diferencia de la práctica periodística el cine documental, no cuenta con un código ético particular, por lo que el peso de las decisiones deontológicas recae en el realizador, como explica Nichols (2007):

Todos los códigos éticos funcionan dentro de un contexto institucional, ya sea la antropología, la medicina o el periodismo. Tales profesiones adoptan códigos éticos, algo que no han hecho los cineastas documentales en su conjunto, en contraste con organizaciones e instituciones susceptibles de producir o emitir material documental, como son las cadenas de televisión o los antropólogos visuales. Se supone que antropólogos, médicos o periodistas cumplen con las normas de su profesión o afrontan las consecuencias en caso de no hacerlo. Sus códigos éticos sirven como mínimo a dos objetivos: proteger los intereses creados del grupo profesional frente a intromisiones externas y proteger los intereses de quienes entran en contacto con este grupo profesional. El sistema de calificaciones empleado con las películas también está al servicio de estas dos funciones, aunque estas calificaciones no equivalgan a un código ético (pp. 29-30).

En la práctica documental, son los cineastas quienes construyen sus propios lineamientos éticos, y son ellos también quienes se enfrentan, con cada película, a las diferentes formas de hacerlo. Deben decidir tomando en cuenta tanto a sus personajes como a la audiencia, deben dejar claro su punto de vista y ser congruentes con él a largo de la película.

En relación al segundo contexto, la tradición documental, nos gustaría recuperar el análisis de algunas películas clave sobre la representación de la pérdida y el dolor como son: Lecciones de Obscuridad (Lektionen in Finsternis, 1992) de Werner Herzog, Gernica (1950) y Noche y Niebla (Nuit et brouillard, 1955) de Alain Resnais, Tierra sin pan (1933) de Luis Buñuel, y Shoah (1985) de Claude Lanzmann.

Para ello recuperaremos el trabajo de Josep María Catalá a propósito de Jean Vigo (2006), el de Nancy Berthier sobre el Gernica de Alain Resnais (2009), 
los aportes de Michael Renov sobre Noche y Niebla incluidos en su libro Theorizing Documentary (1993), los estudios de Mercè Ibarz sobre Tierra sin pan (2000), así como el trabajo sobre el documental de Werner Herzog de la autora de este texto (Alcalá, 2006, 2011).

Partiendo de estos dos contextos: la realizadora y sus emociones, y otros textos y ejemplos documentales sobre el tratamiento de la pérdida y el dolor, planteamos un análisis que revise, en cada etapa del discurso, las decisiones éticas y estéticas del proyecto. En primer lugar los argurmentos (inventio), en segundo el orden narrativo (dispositio) y en tercero las figuras (elocutio).

Para el análisis de las figuras o recursos retóricos, tomaremos como referente la clasificación de imágenes propuesta por Gilles Deleuze (1984-1987). Recordemos que en su taxonomía de imágenes, éste explica cuáles son las características de la imagen-movimiento (imagen-percepción, imagenacción, imagen-afección, imagen-pulsión) y de la imagen-tiempo (imagenmental e imagen-cristal), así como su función estética y cómo éstas se relacionan con textos fílmicos anteriores.

Deleuze, desarrolló sus ideas desde una perspectiva estético-filosófica, planteando una aproximación al cine como instrumento epistemológico, y a sus imágenes como formas de pensamiento, "una nueva analítica de la imagen". Su enfoque pretende ser taxonómico en cuanto clasifica las imágenes y los sonidos, pero su análisis no es estático, al modo de las taxonomías estructuralistas. Sus categorías sirven para reconocer ciertos elementos formales de las películas y sus autores, pero también para anexarlos a otros contextos de interpretación, como la historia del cine, y el pensamiento de la época. Por lo que podemos reconocer distintas lecturas de su obra (Alcalá, 2010 p.118).

Revisar los diferentes niveles de interpretación de sus textos sobre cine, rebasa los alcances de este artículo, pero creemos que lo que sí podemos preguntarnos, partiendo de la obra de Deleuze, es si en el terreno del documental también podemos encontrar algunas imágenes que se repiten en su función ético-estética y cuáles son. 


\section{Análisis del proyecto}

En el siguiente apartado revisaremos cómo son los argumentos principales del proyecto en video, cómo están ordenados los vídeos y qué es lo que cuentan y por último de que recursos se valen para convencer y reflexionar sobre lo que exponen. Todo ello en relación con las categorías de análisis que nos ocupan: la emoción (implicación) de la realizadora y los otros textos sobre documental que nos ayudan a establecer correspondencias en las formas de tratar, desde un punto de vista ético- estético, al dolor y la pérdida en el terreno documental.

\subsection{El mapa. Interfaz y argumento}

En la página Web del proyecto, lo primero que aparece es un mapa de México, en blanco y negro. Sobre él, quince enlaces: once de ellos nos llevan a los videos colocados en el lugar que se corresponde con la historia que se cuenta en el documental, cada uno de un estado de la república diferente. Los otros tres sólo nos dirigen a fotografías y postales.

Los videos están enmarcados, como si fueran retratos colgados en una pared. El resto de ese muro virtual tiene otras imágenes: fotografías de los desaparecidos o de los asesinados, algunos reconocimientos, objetos personales, etc. Así como enlaces a las redes sociales, como podemos ver en la figura 1.

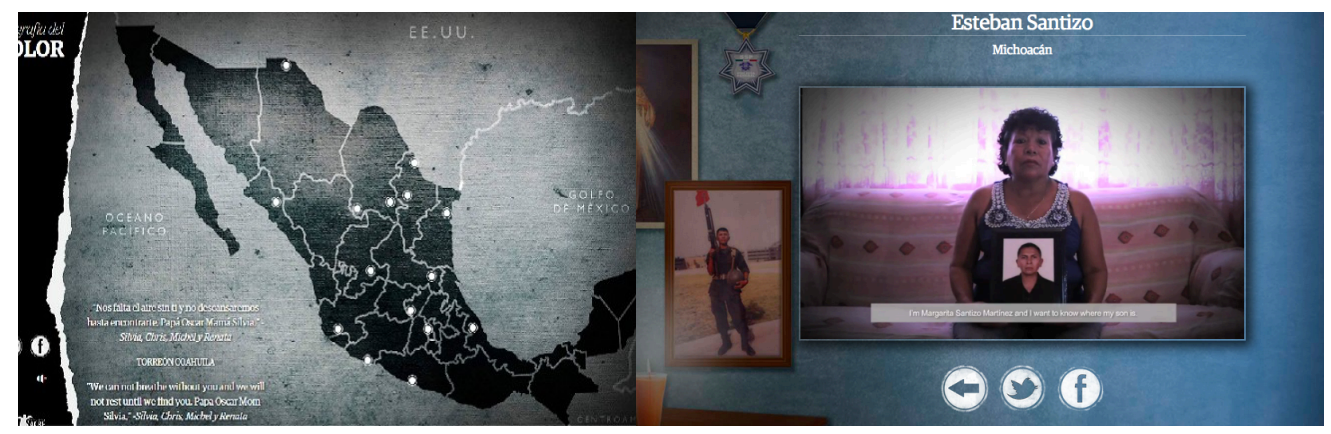

F1. Mapa e imagen de presentación de los vídeos 
El proyecto, como ya mencionamos, se centra en desapariciones y asesinatos durante la guerra contra el narcotráfico en México. Cada video puede considerarse un subtema, un ítem de una especie de tipología de la violencia: madres que perdieron a sus hijos, familiares que buscan a sus desaparecidos, pueblos desalojados y tomados por los cárteles, feminicidios, gobernantes desaparecidos por ser problemáticos para el sistema, trabajadores reclutados por el crimen organizado, etc. como podemos apreciar en la tabla 1.

Tabla 1. La cartografía

\begin{tabular}{|c|c|c|c|}
\hline Estado & Título & $\begin{array}{l}\text { Testimonio } \\
\text { (voz) }\end{array}$ & Caso \\
\hline Chihuahua & Mutilación & Madre & $\begin{array}{l}\text { Asesinato de sus dos hijos en } \\
\text { una fiesta, pensaron que eran } \\
\text { narcotraficantes. }\end{array}$ \\
\hline Sinaloa & Miedo & Desalojado & $\begin{array}{l}\text { Desalojo, con violencia, de un } \\
\text { pueblo entero por un grupo } \\
\text { armado. }\end{array}$ \\
\hline Tamaulipas & Silencio & Familiares & $\begin{array}{l}\text { Desaparición de un grupo de } \\
\text { trabajadores que creían iban a } \\
\text { conseguir trabajo en Nextel, se } \\
\text { sospecha que fueron reclutados. }\end{array}$ \\
\hline Nuevo León & Negligencia & Madre & $\begin{array}{l}\text { Desaparición de su hijo, junto } \\
\text { con otros dos jóvenes. }\end{array}$ \\
\hline Coahuila & Esperanza & Madre & $\begin{array}{l}\text { Desaparición en la carretera de } \\
\text { su hijo, junto con su jefe } \\
\text { empresario. }\end{array}$ \\
\hline $\begin{array}{ll}\text { San } & \text { Luis } \\
\text { Potosí } & \end{array}$ & $\begin{array}{l}\text { Incertidum- } \\
\text { bre }\end{array}$ & Madre & $\begin{array}{l}\text { Desaparición de su hija de } 13 \\
\text { años. }\end{array}$ \\
\hline Jalisco & Desolación & Esposa & $\begin{array}{l}\text { Desaparición de su esposo, un } \\
\text { gobernante rural, que apoyaba } \\
\text { las mejoras del pueblo. }\end{array}$ \\
\hline Querétaro & Desconsue-lo & Hermana & $\begin{array}{l}\text { Desaparición de su hermano } \\
\text { junto con dos amigos en el } \\
\text { estado de Coahuila. }\end{array}$ \\
\hline $\begin{array}{l}\text { Estado de } \\
\text { México }\end{array}$ & Dolor & Madre & $\begin{array}{l}\text { Desaparición de su hija, iba a la } \\
\text { Universidad y nunca llegó. }\end{array}$ \\
\hline Michoacán & Justicia & Madre & $\begin{array}{l}\text { Desaparición de su hijo, policía } \\
\text { federal, junto con dos de sus } \\
\text { compañeros. }\end{array}$ \\
\hline
\end{tabular}




\begin{tabular}{|l|l|l|l|}
\hline Veracruz & Ausencia & Madre & $\begin{array}{l}\text { Desaparición y asesinato de su } \\
\text { hija, se encontró su cuerpo en el } \\
\text { bosque. }\end{array}$ \\
\hline
\end{tabular}

Fuente: Elaboración propia

El mapa permite organizar y dimensionar el problema. Lo primero que nos dice el acomodo de los vídeos es que no hay una zona particular en conflicto, el país entero es escenario de todos estos actos violentos.

La decisión de cartografiar y tipificar los sucesos de esta manera, conlleva una serie de decisiones ético-estéticas. En primer lugar, apreciamos una búsqueda por organizar y clasificar unas serie de acontecimientos de los que no siempre hay información clara: ¿de qué hablamos cuando hablamos de desaparecidos?, ¿estás desapariciones son todas iguales?, ¿quiénes los desaparecen?, ¿todos los desaparecidos son asesinados?, ¿hombres y mujeres son desaparecidos o asesinados por las mismas razones?, ¿tienen la misma edad?, ¿reaparecen?

Estos temas, o bien argumentos en términos retóricos, dejan claro que no hay un único tipo de desaparecido y tampoco un solo agresor, el asunto es más complejo. El enfrentamiento involucra al Estado, a los Cárteles, pero también a Civiles que desafortunadamente se cruzan en su camino. La elección de los casos es un intento por organizar el caos, por detectar algunos actores importantes en un juego perverso y desinformado. Si lo leemos de esta manera, vemos claramente cómo la vocación periodística de la realizadora se asoma en este esfuerzo de organización y de clasificación del problema, una decisión ético-estética: retratar los casos más representativos para poder entender qué está pasando.

El mapa no es exhaustivo en cuanto al número de desaparecidos o asesinados, sino de las formas en que se cree fueron violentados. Los números son inciertos, la forma en que se los llevaron y las razones por lo que lo hicieron simplemente se sospechan, pero no hay una confirmación por parte de ninguna autoridad, nadie sabe nada. Cada video explica un caso que 
se argumenta a través del relato de lo que se cree pudo haber pasado, o de lo que se presiente está sucediendo.

\subsection{El testimonio. Orden y estructura narrativa}

Las 11 historias están narradas por los familiares de las víctimas, los relatos se organizan de las siguiente manera: primero se presenta el familiar; en segundo lugar éste explica, con sus propias palabras, el caso, desaparición, asesinato, desalojo, etc.; en un tercer momento narra los esfuerzos de búsqueda, los callejones sin salida, las extorsiones, las amenazas, etc.; luego describe cómo este suceso le ha cambiado la vida, la ruina emocional, económica, la destrucción de su familia, etc.; y por último, le dedica un mensaje a ese familiar desaparecido o asesinado. ¿Qué le diría si lo tuviera frente a frente?

Todos los videos comienzan con una única palabra sobre fondo negro, que sintetiza el sentimiento de las víctimas: mutilación, miedo, silencio, negligencia, esperanza, incertidumbre, desolación, desconsuelo, dolor, ausencia y justicia.

Este preludio gráfico es menos ensayístico, en el sentido de la utilización de texto como una forma discursiva más del propio filme, que más bien nos recuerda a los títulos que acompañan a las fotografías, como si estuvieran expuestas en una galería. Esa palabra única describe, contextualiza y enmarca el relato documental como si se tratara de una imagen fija, en la que el título ayuda a la comprensión de la fotografía. La palabra aparece en fondo negro y permanece los suficientes segundos para que la voz en off comience el relato antes de desaparecer.

La voz es siempre la de los familiares, principalmente de las madres, ellas protagonizan siete de los once videos. Los cuatro restantes los narran: una esposa, una hermana, un grupo de familiares y un habitante del pueblo desalojado quien perdió a su primo en el evento, como observamos en la tabla 1. 
El peso narrativo de los videos está en esta voz. Como hemos visto en otros documentales del modo interactivo, en los que la importancia de la historia está en los testimonios, en palabras de Bill Nichols (1997):

El documental interactivo hace hincapié en las imágenes de testimonio o intercambio verbal y en las imágenes de demostración (imágenes que demuestran la validez, o quizá lo discutible, de lo que afirman los testigos)... la autoridad textual se desplaza hacia los actores sociales reclutados: sus comentarios y respuestas ofrecen una parte esencial de la argumentación de la película. Predominan varias formas de monólogo y diálogo (real o aparente) (p. 76).

Como Claude Lanzmann en Shoah (1985), la realizadora de Geografía decide hacer un proyecto testimonial. Con la diferencia de que en la película sobre sobrevivientes del holocausto, los entrevistados vivieron el horror de los campos en el pasado y en primera persona, mientras que la historia sobre desaparecidos es una historia del presente, explicada desde quienes los buscan o sufren su muerte. Ambas son testimoniales, ambas interactivas en la tan discutida clasificación de Nichols, y ambas con la publicación de un libro además de la película, en un espíritu de extender el relato y llegar a un público más extenso. Los dos proyectos parten de la idea de crear conciencia y de reflexionar sobre un tipo de guerra y sus crueles consecuencias. Son episódicos porque cada caso es una historia nueva que completa el mosaico general.

En todo momento se escucha el relato en off. En ocasiones parece no tener nada que ver con las imágenes, como si caminara en paralelo para crear este doble discurso entre lo que se ve y lo que se escucha, dejando que sea el espectador el que yuxtaponga las escenas y complete la historia. El proyecto retrata un episodio complicado y doloroso que no puede contarse de una sola manera porque, como mencionamos, en la estructura narrativa queda claro que importa tanto el acontecimiento como el sentimiento de dolor y pérdida del familiar, y el video habla de ambos todo el tiempo, como si se tratara de dos historias que simplemente no pueden separarse. 
La memoria juega un papel primordial, los detalles se vuelven clave para tratar de entender qué pasó. Los familiares regresan al día de la desaparición y/o asesinato una y otra vez, para tratar de reconstruir un momento en el que no estaban presentes pero que cambió su vida completamente. De pronto su percepción ha mutado, el tiempo se concibe de otra manera, como siempre después del trauma, como señala Berson (1911):

...Y quien ve surgir frente a sí, de improviso, la amenaza de una muerte repentina, para el alpinista que resbala por un precipicio, para los ahogados y los ahorcados, por ejemplo, parece que puede producirse una transformación brusca de su atención -algo así como un cambio de orientación de la conciencia, que, hasta entonces volcaba su atención hacia el futuro por las necesidades de la acción, de manera que súbitamente pierde tal fascinación. Esto basta para que miles y miles de detalles "olvidados" sean recordados, para que la historia entera de la persona transcurra como una película ante sus ojos, en forma de panorama cambiante (p. 169).

La voz trata de explicar mientras las imágenes se muestran autónomas, haciendo énfasis en este cambio de percepción en el que los detalles son recordados pero difícilmente pueden ser asimilados. Una memoria fragmentada de un acontecimiento sin registro alguno, los familiares tratan de revivir un suceso que no presenciaron, de reconstruirlo con la escasa información y el dolor que implica preguntarse qué pasó realmente.

\subsection{Figuras, recursos ético-estéticos: una tipología de imágenes}

Cada video se organiza narrativamente a través del relato testimonial, las imágenes que acompañan el discurso ilustran o ejemplifican eso que nos está contando él o los familiares en off. Sin embargo, como hemos explicado, no todas las imágenes que encontramos en los videos tienen exclusivamente esta competencia ilustrativa, algunas de ellas funcionan también como figuras retóricas (metáfora, sinécdoque, repetición, elipsis, etc.) o bien como recursos ético-estéticos. En este apartado revisaremos algunas de ellas y su relación con otras obras documentales, que trabajan sobre la representación del dolor y la pérdida. 


\section{3•3.1. Imágenes-silencio}

La forma de presentar a los familiares - narradores de los videos- es con una imagen de retrato doble, en ella se muestra al familiar sosteniendo una fotografía del desaparecido y/o asesinado. No hay ninguna acción, sólo el gesto de sujetar y de estar siendo filmado. Unos segundos sumamente expresivos en los que parece no suceder nada, pero que están cargados de tensión y emoción. Son un retrato en movimiento, acompañado por música dramática y el relato informativo-descriptivo en voz en off.

Hablamos de imágenes-silencio porque en ellas aparentemente no sucede nada, no nos cuentan más de la historia sino que tienen una función distinta, son más expresivas que narrativas. Son una respuesta a como tratar el dolor y la pérdida, porque en estas imágenes vemos a los familiares desorientados, expuestos, cansados, sin palabras. Enmudecieron de tristeza, de desesperación, pero no porque no puedan hablar los estamos escuchando en off, sino porque con este gesto simbólico se enfatiza el drama que están viviendo.

No son mudos como la mujer que entrevista Werner Herzog en Lecciones de Obscuridad (1992), a la que observamos tratando de explicar, a través de sonidos guturales incomprensibles, las consecuencias del paso de las tropas iraquíes por Kuwait. Recordemos que: “Lessons of Darkness narra uno de los mayores desastres ecológicos del mundo, que quedó al descubierto tras la retirada de las tropas iraquíes de Kuwait: incontables pozos de petróleo ardían e iban a parar al mar. Estamos contemplando el Apocalipsis, a través de imágenes aéreas de una cámara que se desliza por encima de las llamas, de la mano de la música de Wagner" (Alcalá, 2007, p. 36).

Sin embargo, ambas representaciones, tanto la de los retratos en Geografía como la entrevista de la mujer sin voz, son imágenes-silencio, ya que explican de forma metafórica que no hay palabras para describir el dolor. Son un recurso ético-estético para dimensionar las consecuencias de la guerra y, sobre todo, el estado en que se quedan las víctimas. 
La disociación entre la voz de fondo y el retrato mudo potencia la desesperación de los familiares, pero también los protege de estar contando una historia que no puedan continuar frente a cámara. Les permite pausar su relato las veces que sea necesario y los cuida de no tenerlos rotos, incómodos o llorando a cuadro. No nos apartamos de la intención persuasiva de los videos, pero no es necesario exhibir a los familiares, lo importante es contar qué sucedió y retratar en qué estado quedaron las víctimas.

Nuevamente aparece la vocación periodística de la realizadora, que se esfuerza en que el relato en off brinde los datos sobre el caso y las víctimas, pero también su preocupación por retratar sin violentar, valiéndose del ejercicio de la fotografía sin voz, como si se tratara de una imagen fija, pero trasladado al las imágenes en movimiento, convirtiéndolas así en imágenessilencio.

\subsubsection{Imágenes-prueba}

Para tratar de explicar los esfuerzos de búsqueda y los callejones sin salida, en cada una de las historias la realizadora recurre a la utilización de material de archivo: algunas veces de otros medios, y la mayoría, de documentos grabados por ella y su equipo en las distintas marchas, manifestaciones y eventos de protesta o búsqueda.

En "Mutilación”, por ejemplo, utiliza imágenes de archivo de la visita del ex presidente Felipe Calderón a Chihuahua, en las que vemos a Luz María Dávila interrumpir una rueda de prensa para exigir que deje de referirse a sus hijos asesinados como narcotraficantes, que ellos eran estudiantes, estaban en una fiesta y los acribillaron por error, los militares "simplemente" se confundieron de dirección. Las imágenes provienen de un noticiero, el sonido se sobreimpone con el de la voz en off creando un discurso reiterativo: un lamento por duplicado. Son imágenes ya vistas, transmitidas por televisión pero que pasaron desapercibidas, por lo que hay que volverlas a mirar. 
Las imágenes de marchas y de protestas son parte de casi todos los videos, sobre todo de los que se refieren particularmente a desapariciones. En estas imágenes, los familiares protagonistas de los videos se confunden entre el grupo, porque como ellos hay muchos otros buscando a sus desaparecidos. En la voz en off escuchamos la historia de uno, mientras que en las imágenes vemos que forman parte de un colectivo mucho mayor ${ }^{3}$.

Estas imágenes podrían parecer simples ilustraciones del relato que estamos escuchando, sin embargo, creemos que además de ilustrar tienen otra función ético-estética: trascender la historia que se cuenta, es decir, ser sinécdoque de un problema más complejo. No son los únicos casos de desaparecidos, y no hay estadísticas, no podemos decir cuántos son, el proyecto está, desgraciadamente, en construcción. Como nos muestra la figura 2, en primera fila está la madre de Daniel, pero alrededor suyo hay tantos otros familiares cargando con sus desaparecidos o con sus fotografías. Los casos que explica el proyecto Geografía son muy pocos en comparación con todos los que existen en el país.

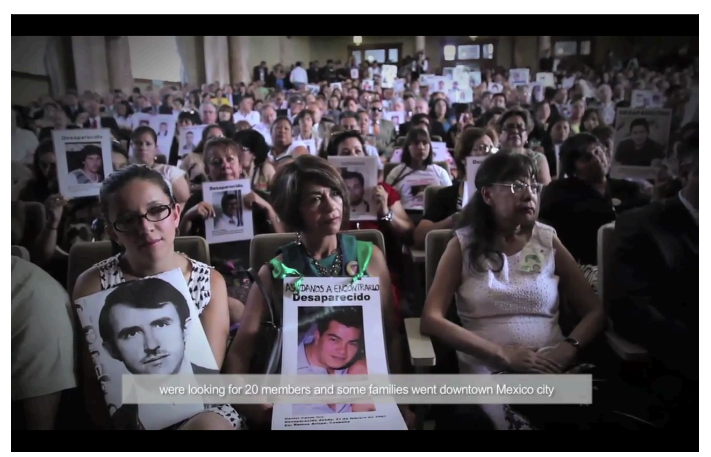

F2. Imágenes-prueba

Nos referimos a ellas como imágenes-prueba, ya que corroboran el argumento pero extienden su dimensión. Nos atrevemos a plantear un paralelismo con la imágenes de Tierra sin pan (1933), en las que Buñuel nos muestra la realidad de los hurdanos como gesto sinecdótico de otros tantos pueblos en condiciones de pobreza en la época. El tono surrealista del filme

3 El único caso que es narrado en plural es el de "Silencio", en el que desaparecieron a un grupo de trabajadores que fueron engañados con la promesa de que iban a ser contratados por Nextel, pero en lugar de eso se sospecha que fueron reclutados por los Cárteles. 
del realizador aragonés, por supuesto no es el del proyecto Geografía, pero la fuerza de sus imágenes en contraste con la voz, es la que nos permite trazar este posible eco.

Tierra sin pan es un filme único, como señala Ibarz (2000), que marcó un antes y un después en el terreno de la denuncia social y de la propaganda. Con su película, Buñuel hizo evidente el poder de contrastar la voz con las imágenes, aparentemente informativas y exclusivamente descriptivas, pero que en conjunto pueden crear un discurso reflexivo mucho más sofisticado y potente:

Así lo hace muy específicamente Tierra sin pan. Tradicionalmente, y por ser el único documental de su autor y un film en este sentido de registro único, sin parientes ni escuela, el film hurdano ha sido visto por la historia del cine documental no como un modelo posible sino como una pieza que enriquece el género por ser precisamente de Buñuel. Pero lo cierto es que en su misma unicidad -cierto, es único- el film debe ser visto en su cualidad de caja de resonancia histórica, en su capacidad de revelar el pasado, de contarlo y de elevarlo al estadio de mito. Que hoy le pidamos algo distinto al documental habla de nosotros, de nuestra historia reciente (televisiva) y de las vicisitudes que el género ha sufrido desde los inicios del sonoro, momento en que, precisamente, Buñuel traza con tiralíneas la geometría de su acercamiento a Las Hurdes en el contexto de la España que, en 1933, se debate entre la revolución, la reforma y el fascismo. En aquel mismo año, Robert y Frances Flaherty rodaban en las islas de Aran su empatía con un tipo de vida no tan alejada de la hurdana, y aunque Buñuel se indigna donde Flaherty se decide por idealizar y cantar, los dos films comparten una misma cualidad: son relatos míticos (p. 1)

La realizadora de Geografía intenta documentar desde un punto de vista periodístico. En sus imágenes se explican once casos, pero también se cuenta otra película, la que está fuera de campo. Estas imágenes-prueba hablan de ella y se vuelven un recurso ético-estético, ya que rebasan el caso y explican un poco más del conflicto: son muchos más familiares buscando a sus desaparecidos, más de los que imaginamos, muchos más de los que vemos en pantalla. No hablamos de un filme mítico, por supuesto, pero reconocemos el 
poder reflexivo de trabajar con este tipo de imágenes, que al mismo tiempo que ilustran, rebasan el tema provocando una reflexión mayor. Desbordando el acontecimiento y replanteando la necesidad de darle voz a tantos otros familiares, que están en las mismas condiciones que los protagonistas de Geografía.

\section{3•3.3. Imágenes- testimonio}

Nancy Berthier en su artículo sobre Gernica y la imagen-ausente (2009), explica que "la ausencia de imágenes que sirvan de indicio del suceso no sólo no es un problema insuperable, sino que, muy al contrario, se revela casi como una ventaja” (p. 102). Argumenta que la película de Resnais sobre el bombardeo de la ciudad vasca es un claro ejemplo de este acierto creativo:

De este modo tan sutil, Alain Resnais logra combinar con acierto los dos temas de su documental (el cuadro y el suceso). Al no apostar por las imágenes mecánicas -que eran inexistentes-, sino por las imágenes artísticas - las de la obras de Picasso-, podría decirse que el cineasta se adentra en la esfera expresiva del pintor, caracterizada por una representación no realista de los hechos que despoja al suceso de su dimensión referencial para acentuar la universalidad de su alcance (p. 105).

En el caso de Geografía tampoco tenemos imágenes del suceso, no hay ningún registro de las desapariciones, por lo que la realizadora se valdrá, no de un cuadro como el de Picasso, pero si de otro tipo de imágenes que sustituyan y sobre todo remarquen de forma simbólica y poética la ausencia: del retrato de los espacios vacíos. No se cuenta con una obra plástica como tal, pero debemos reconocer que hay cierta plasticidad en estas imágenes, ya que tienen una vocación pictórica, principalmente romántica, puesto que fueron testigo de un acto siniestro.

En "Negligencia”, la cámara recorre una y otra vez la presa en la que fue visto por última vez Julio Alberto, quien desapareció junto con dos amigos cuando daban un paseo en lancha el 12 de enero de 2008 en Santiago, Nuevo León. En "Ausencia” las imágenes son del bosque. Como en el caso anterior, la 
cámara interroga al paisaje. En este lugar desapareció Gabriela, de 17 años, y tres meses después ahí mismo apareció su cadáver. Nadie sabe qué sucedió en ese tiempo, el único testigo: el bosque, que observa enmudecido.

La carretera, el lago, el bosque, se transformarán en testigos de la tragedia, y la cámara hace un esfuerzo por darles voz, los recorrerá una y otra vez, tratando de interrogarlos a través de la repetición. Las de este tipo son imágenes-testigo, caracterizadas por el uso de la cámara lenta y del traveling. Su finalidad es detener el tiempo para entender qué pasó ahí, en la tradición documental hay muchos de ellos, por ejemplo:

...en Lessons of darkness (1992), la cámara recorre lentamente, una habitación en la que están expuestos instrumentos de tortura. Están colocados, uno al lado del otro. Son aparatos hechos de objetos de uso cotidiano, como puede ser una botella de refresco rota, una tostadora, o una silla a la que han cambiado el asiento por una parrilla eléctrica. En la escena no sucede nada, sólo asistimos a la exposición, al travelling que recorre la habitación y sus objetos que, anteriormente, fueron escenario y armas de tortura. El duelo y el dolor se manifiestan en la ausencia, en el movimiento de cámara que carga consigo las sombras del pasado. Sus usos han sido negados, no registrados, pero no por ello desaparecen. Un gesto al que hemos asistido antes en el cine documental, visitando el escenario de los campos de concentración nazi, diez años después de terminada la guerra, en la síntesis de pasado y presente que retrató de forma magistral Alain Resnais en Nuit et brouillard (Alcalá , 2007, 166-167).

Los espacios vacíos se transforman en imágenes-testimonio cuando sabemos que presenciaron el horror y sobrevivieron a él. La violencia es irreversible pero a veces no deja huella, sólo paisajes mudos que no arrojan luz sobre los hechos pero si nostalgia, muchas veces dolor, y permanecen como fondos para la construcción de la memoria.

\subsubsection{Imágenes-altar}

¿A dónde llevo flores a mi hijo? Se pregunta Julia Alonso, madre de Julio, desparecido en Michoacán, haciendo hincapié en la desesperación de no 
saber cómo lidiar con el dolor y anhelando una respuesta. Si estuviera muerto su hijo habría una tumba, pero sólo está desaparecido.

Esta sensación de incertidumbre, además de ser parte del relato de los familiares, también se observa en un tipo de imágenes que llamaremos imágenes- altar. Éstas son instalaciones hechas por los familiares, compuestas principalmente por fotografías del desaparecido, sus objetos personales, imágenes religiosas y flores, casi siempre artificiales.

Nos parece que estas instalaciones tipo bodegón ilustran el sentimiento de dolor y pérdida, y que al hacerlo se transforman en poderosos íconos de las consecuencias de esta guerra. Son altares en el sentido de que sirven para rezar, para mantener la esperanza de encontrar a sus desaparecidos pero también hablan de muerte, y por tanto se convierten en sus propias tumbas.

Encontramos una posible filiación entre las imágenes-altar de los videos de Geografía y la serie de Vanitas, en las que la muerte tiene una presencia protagónica. Por supuesto, en las imágenes-altar de Geografía el elemento “vanidad” no está presente, pero sí el de la muerte y por supuesto el del dolor causado por la ausencia. Estas imágenes, según Català (2006), tienen las siguientes caractarísticas:

... la serie de Vanitas que proliferaron sobre todo en la pintura holandesa del siglo XVII y que pretendían alegorizar, precisamente, la vanidad de la vida humana. Como los bodegones, estos cuadros se componen de un repertorio de objetos de la vida cotidiana, pero al contrario que en ellos, estos objetos adquieren en las vanitas, por la presencia de la muerte simbolizada por calaveras u otros objetos funerarios, un tono muy distinto: la aparición de la muerte cae como una sombra sobre todos ellos y los desfamiliariza. Algunos de estos objetos se convierten entonces en simbólicos o ya lo son de antemano: un reloj de arena puede simbolizar el paso del tiempo; los objetos de oro o plata representan la riqueza; los libros, el conocimiento; los instrumentos de música se refieren a las diversiones, etc. Pero este proceso de simbolización no es el fenómeno más importante que caracteriza las vanitas y el que realmente transfigura sus objetos, sino que lo más trascendental es que estos, que en un bodegón (que sería 
equivalente a un documental) se referirían miméticamente a una realidad sin aparentes cualidades, adquieren de inmediato, al contacto con la muerte, un aire siniestro que contradice su propia evidencia visual inmediata. Cuanto más rico, más placentero, más atractivo es un objeto incluido en una vanitas, más siniestro se vuelve a los ojos del espectador, que lo contempla a través del filtro de su inevitable carácter perecedero. Así cada objeto, incluso cada símbolo objetivado por él, se convierte en su propia negación. Una vanitas es una configuración visual que niega el deseo que ella misma se empeña en provocar en el espectador (pp. 56 57).

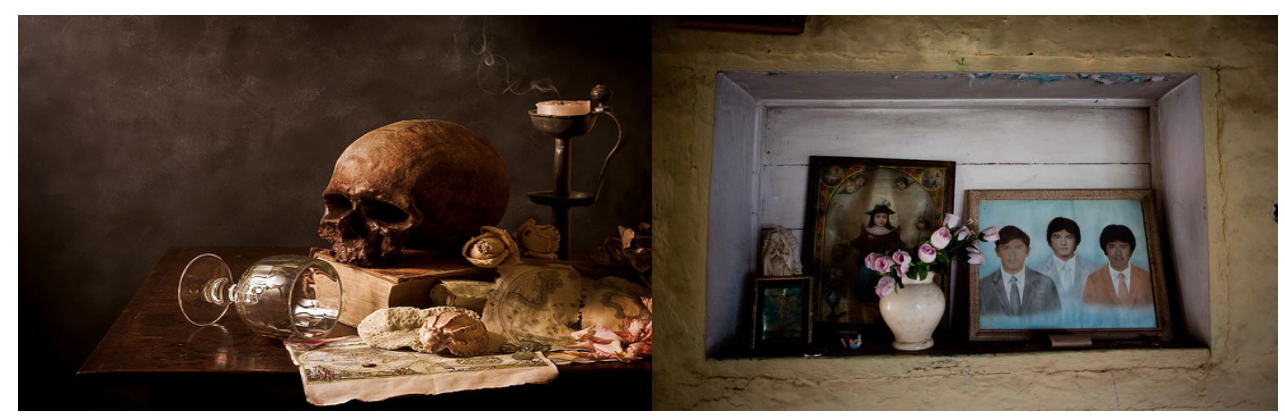

f3. Imágenes-altar

En las imágenes-altar las fotografías ocupan el lugar principal, suelen ser escenas de infancia, de graduaciones, de momentos felices, hablan de vida; mientras que las flores artificiales y las imágenes religiosas aportan el elemento siniestro, en ellas se asoma la angustia: la muerte. Como podemos observar en la figura 3, la Vanitas juega con la idea de vanidad y muerte en un sentido universal, con pretensiones artísticas, además, mientras que la imagen extraída del proyecto Geografía nos sitúa en un contexto violento y local. Estos altares son el símbolo de la cultura mexicana que está de luto por todos los desaparecidos, son sus altares, con sus colores y texturas.

Estas imágenes-altar, en la mayoría de los videos, se recorren en un pequeño traveling mientras escuchamos la última parte de los testimonios de los familiares, la que corresponde a lo que le dirían si tuvieran a su hijo, hija, esposo o hermano frente a frente. Esta información se repite en las postales 
que escriben para sus familiares, como podemos observar en la figura 4, y que se encuentran debajo del vídeo.

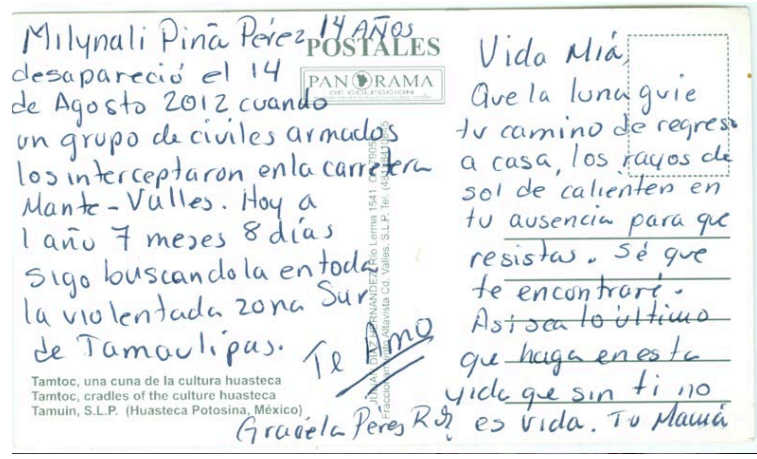

F4. Postales

Utilizar imágenes cuya intención va más allá de la descripción, nos muestra el uso de figuras retóricas en el documental: las imágenes-silencio son metafóricas puesto que su silencio es simbólico y ayuda a exponer el dolor desde el respeto; las imágenes-prueba son sinécdoticas en el sentido de que dejan ver que el universo de casos es mucho mayor; las imágenes-testigo son elipsis, puesto que en esos paisajes desolados conviven el presente y el pasado trágico; por último, las imágenes-altar son el elemento iconográfico que sirve como alegoría, como síntesis de la frontera entre la desaparición y la muerte.

\section{Conclusiones}

El proyecto Geografia del Dolor retrata las consecuencias de una guerra que aún no ha terminado. En la que es muy difícil detectar al enemigo y que ha servido para generar muchos otros actos violentos, como la extorsión, el abuso de poder, la impunidad política, etc. Las víctimas son los desaparecidos pero también sus familiares, que cada día se levantan con la esperanza de encontrar, vivo o muerto, a su hijo, hermano o esposo. La intención del proyecto es darle voz a estos familiares, prestar atención a su reclamo, a su dolor, a su miedo.

Este retrato es delicado, por el estado de las víctimas el tema requiere respeto, una postura ética que se transforme en estética para contar los 
sucesos y la desesperación de quienes sobreviven tratando de entender qué pasó, y cuándo terminará la angustia. Estas decisiones ético-estéticas son tomadas por el realizador, quien se enfrenta al tema con su propio bagaje cultural y personal.

Las emociones de la realizadora se perciben en el proyecto desde la primera decisión: centrarse en las víctimas, pero también en algunas otras, como la búsqueda por tipificar los actos violentos y por apelar directamente a las emociones del espectador, que no puede quedarse indiferente después de escuchar los relatos de los familiares, quienes concluyen cada video con lo que le dirían a su ser querido si lo tuvieran frente a frente. Me parece que leer Geografía desde las emociones del autor no sólo es un acierto, sino una necesidad por el nivel de implicación de la realizadora.

Nos parecía importante revisar cómo los recursos que utilizan los videos de Geografía ya los habíamos visto antes, es decir, cuando se trata de representar el dolor y la pérdida, muchos otros documentalistas clásicos ya se habían preguntado cómo encontrar la estética adecuada para aproximarse a ciertas historias que requieren un compromiso ético mayor. Ya que, como pudimos observar, el cuestionamiento ético en el documental va de la mano de la solución estética y depende del realizador.

Utilizar el punto de vista hermenéutico en el análisis fílmico propone trazar un camino de ida y vuelta a los textos. Primero reconocer en qué contextos se sitúan, luego extraer de ellos las categorías de análisis para después volver a interpretar los filmes con dichas categorías. Este ejercicio requiere, como pudimos observar, el soporte de otras disciplinas, así como de otros pensamientos teóricos que acompañen y respalden el proceso. El rigor depende también de estas elecciones.

En el caso del proyecto Geografía, partimos de las emociones de la realizadora y de la tradición documental, y funcionó, pero como podemos ver estas ópticas no son las únicas, perfectamente pudimos seleccionar otros contextos y crecer los círculos hemenéuticos. Por lo que habrá que tener cuidado al definir qué queremos analizar en las películas: como nuestra 
intención era revisar los recursos con los que se representa el dolor y la pérdida en el proyecto de Mónica González, estos contextos fueron suficientes, pero no profundizan sobre el problema de violencia en México, ni sobre las particularidades del proyecto en la web, otros temas que se descuidan en esta lectura propiamente cinematográfica y documental.

La recuperación de otros análisis de filmes, en este caso todos documentales, fue una apuesta arriesgada pero sumamente interesante, porque nos permitió trazar diálogos con otras miradas teórico-metodológicas, darnos cuenta de cómo llegan estos autores a sus conclusiones sobre una película $u$ otra, y ver si es posible trazar una similitud con el proyecto que estudiamos, para así continuar la reflexión sobre el cine documental entendiendo la distancia entre los autores y entre los productos. Pero cuando se trata del explorar el terreno de lo real parece que podemos acortar algunas de estas distancias, si tomamos las precauciones pertinentes.

\section{Referencias bibliográficas}

Alcalá 2007. El papel de lo real en el cine de Werner Herzog. En Weinrichter (Ed.) Caminar sobre hielo y fuego. Madrid: Ocho y Medio.

Alcalá 2010. Lo irónico-sublime como recurso retórico en el cine de noficción de Werner Herzog. El caso de The White Diamond, Grizzly Man y The Wild Blue Yonder. Tesis de Doctorado. Universitat Pompeu Fabra.

www.tesisenxarxa.net/TDX-0126110-125519/

Bergson, H. (1993) La perception du changement, conferencia impartida en Oxford el 27 de mayo de 1911 incluida en La pensée et le motivante, París, P.U.F., Colección Quadrige, 1993, pp. 168-170.

Berthier, N. (2009). Guernica o la imagen ausente. Archivos De La Filmoteca, (61), 96-113.

http://www.archivosdelafilmoteca.com/index.php/archivos/article/vi ew/64/152

Català, J. (2006). Vigo en las ciudades. La construcción de un punto de vista moral. Archivos De La Filmoteca, (52), 42-63.

http://www.archivosdelafilmoteca.com/index.php/archivos/article/vi ew/275/276 
Dubois, P. (2013). Fotografía y cine. Oaxaca, México: Televisa, Fundación Cultural.

Franco, D. (2014). Mónica González. Hay que retratar las consecuencias del dolor, no únicamente su violencia. Testigos presenciales. Entrevista on-line recuperada de:

http://nuestraaparenterendicion.com/testigospresenciales/monicagonzalez/

Gadamer, H. (2007) Verdad y Método. España: Ediciones Sígueme Salamanca.

Ibarz, M. (2000). Surrealismo, historia, contexto mediático y pedagogía, en Tierra sin pan(Buñuel, 1933). Revista Film-Historia, 1-2,

http://www.publicacions.ub.es/bibliotecaDigital/cinema/filmhistoria/Art.Ib arz.pdf

Nichols, B. (1997). La representación de la realidad: cuestiones y conceptos sobre el documental. Barcelona, España: Paidós.

Nichols, B. (2007). Cuestiones de ética y cine documental. Archivos De La Filmoteca, (57), 27-45.

http://www.archivosdelafilmoteca.com/index.php/archivos/article/vi ew/204/207

Renov, M. (1993). Theorizing Documentary. New York: Routledge.

Geografía del Dolor, Docuweb: http://www.geografiadeldolor.com/

Cómo citar: Alcalá Anguiano, F. (2016). "La representación del dolor y la pérdida en el cine documental. El caso de Geografía del Dolor". Fotocinema. Revista científica de cine y fotografía, $\mathrm{n}^{0}$ 12, pp. 312-335. Disponible: http://www.revistafotocinema.com/ 